\title{
The Role of Humoral Mediators in Migraine Headache
}

\author{
A. FANCHAMPS
}

SUMMARY: The classical vascular mechanism of migraine attacks demonstrated by Wolff - intracranial vasoconstriction during the prodromal stage and passive vasodilatation of extracranial arteries during the painful phase - has been confirmed by modern methods. Arterial distension is, however, not sufficient to explain the origin of the pain: to give rise to an acute migraineous pain, it must be associated with a lowered pain threshold of the receptors situated in the wall of the affected vessels. A number of humoral factors - plasmakinin, serotonin, histamine - intervene in the chain of events that culminates in migraine headache.

At the start of the attack, the blood platelets release serotonin, the mast cells in the affected area release histamine and proteolytic enzymes that split plasmakininogens to form plasmakinins. Free serotonin and histamine increase capillary permeability and

RÉSUMÉ: Le mécanisme vasculaire classique de la crise migraineuse mis en évidence par Wolff - vasoconstriction des vaisseaux craniens pendant les prodromes et vasodilatation passive des artères extracraniennes à la phase douloureuse - a été confirmé au moyen de méthodes modernes. La distension artérielle ne suffit cependant pas à expliquer la genèse de la crise; pour provoquer une douleur migraineuse, elle doit être associée à un abaissement du seuil douloureux des récepteurs situés dans la paroi des vaisseaux atteints. Divers facteurs humoraux - plasmakinine, sérotonine, histamine - interviennent dans l'enchaînement des phénomènes qui aboutissent à la céphalée migraineuse.

Au début de la crise, les plaquettes sanguines libèrent de la sérotonine, les mastocytes de la région atteinte libèrent de l'histamine et des enzymes protéolytiques scindant les plasmakininogènes en plasmakinines. La sérotonine et l'histamine libérées augmentent la perméabilité et favorisent la transsudation de plasmakinine dans les parois des favor transudation of plasmakinin into the vessel walls and perivascular tissues. The combined effect of serotonin and plasmakinin on the vessel wall receptors reduces their pain threshold. On the other hand, the bulk of the released serotonin is excreted as 5-HIAA, and plasma serotonin falls. Since serotonin has a constricting effect on the extracranial arteries and a dilating one on the capillaries, the fall in its plasma level induces hypotonia of these arteries and capillary constriction, which results in a passive distension of the arterial walls. The two factors necessary for the production of pain are thus present: a low pain threshold and vascular distension.

In addition to these three main humoral mediators, the part played by tyramine in migraine of alimentary origin, the precipitating effect of estrogen decrease in mentrual migraine and the hypothetical role of prostaglandins and prolactin are discussed.

vaisseaux et les tissus périvasculaires. L'effet conjugué de sérotonine et de plasmakinine sur les récepteurs des parois abaisse leur seuil douloureux. Par ailleurs, la plus grande partie de la sérotonine libérée est excrétée sous forme d'acide 5-HIA, et la sérotoninémie s'abaisse. La sérotonine ayant un effet constricteur sur les artères extracraniennes et dilatateur sur les capillaires, la chute de son taux plasmatique s'accompagne d'un hypotonus de ces artères et d'une constriction capillaire, aboutissant à une distension passive des parois artérielles. Les deux facteurs nécessaires à la genèse de la douleur sont dès-lors réunis: distension vasculaire et abaissement du seuil douloureux.

En plus de ces trois principaux médiateurs chimiques, l'action de la tyramine dans les migraines d'origine alimentaire, l'effet déclenchant de la baisse du taux d'oestrogènes dans les migraines menstruelles, et le rôle hypothétique des prostaglandines et de la prolactine sont discutés.

\section{THE CLASSICAL VASCULAR THEORY}

According to the American "Ad hoc Committee on Classification of Headache", migraine belongs to the group of "vascular headaches".

The vascular mechanism of migraine attacks has been thoroughly studied and documented by Wolff and his co-workers $(1948,1963)$. Their conclusions - intracranial vasoconstriction in the prodromal phase and vasodilatation, especially extracranial, in the pain phase - are still valid today, and have been confirmed with the aid of modern techniques. Thus, Skinhøj and Paulson (1969 and 1971) measured regional cerebral blood flow with the intracarotid ${ }^{133} \mathrm{Xe}$ injection method and found a diminished flow during the prodromata and an increased one during the painful phase. O'Brien (1971) obtained similar findings with the ${ }^{133} \mathrm{Xe}$ inhalation method.

These vascular changes do not however tell the whole story. It had long been observed, for instance, that in the course of a unilateral migraine attack the temporal arteries on both sides can be hyperpulsating (Graham and Wolff, 1937), and that in migraine patients distension of these arteries may be seen not only during attacks, but also on the days preceding them, i.e. outside the painful phases (Wolff, 1963).

\section{HUMORAL MECHANISMS}

As early as 1958 it was demonstrated that the sensitivity of the conjunctival vessels to noradrenaline is increased before and very

Medical Counsel, Pharmaceutical Research \& Development, Sandoz Ltd., Basle, Switzerland.

Reprint request to Dr. A. Fanchamps M.D., c/o Sandoz Ltd., CH-4002 Basle, Switzerland. 
greatly reduced during the migraine attack (Ostfeld et al., 1958); it is likely that this phenomenon, readily observable in the eye, also affects other vessels of the head.

The role of humoral factors in precipitating migraine headaches has received growing attention in the past decade, especially on the part of the groups headed by Wolff in New York, Sicuteri in Florence, Lance in Sydney, and various English and Scandinavian authors.

Let us first review the most salient findings:

-During the attack, local edema due to increased capillary permeability develops around the extracranial vessels in the painful zone. The deep pain threshold in this zone is lowered (Wolff, 1963).

- The perivascular edematous fluid contains a polypeptide of the plasmakinin type, called "neurokinin" by Wolff. The blood level of plasmakininogen is reduced, indicating increased formation of plasmakinin (Wolff, 1973).

-Kangasniemi et al. (1972a) found an increase in proteolytic enzymes in the cerebrospinal fluid of half of migraine sufferers during and after an attack; these proteolytic enzymes are capable of splitting plasmakinogens to form plasmakinins.

- The mast cells in the skin and scalp of the painful zone are decreased in number and degranulated during and after the attack (Sicuteri, 1963). This degranulation implies liberation of histamine, proteolytic enzymes (Hopsu et al., 1963) and possibly serotonin.

These facts all point to the conclusion that plasmakinin is formed during migraine attacks. Plasmakinins are known to provoke local pain and to lower the pain threshold. It is thus logical to assume that a plasmakinin, which with Wolff we may call "neurokinin", plays a role in the pathogenesis of migraine pain.

This is not, however, the only element at work, for other findings have implicated other biogenic amines.
During the attack, the mast cells also release histamine. This endogenous substance produces a short lasting vasodilatation and increases permeability.

The role of histamine in classical migraine appears to be limited to enhancing permeability, which favors transudation of plasmakinin. The vasodilator effect is probably not an important factor, in that Wolff (1963) has demonstrated that the short-lived headache caused by an injection of histamine is essentially due to intra-cranial vasodilatation, and not extracranial as in migraine headache.

Histamine plays a leading role, on the other hand, in cluster headache, or Horton's histaminic cephalgia. In subjects suffering from this syndrome, injection of histamine gives rise to a typical attack. Lance's group also recently demonstrated that the blood histamine level is increased during attacks of cluster headache, which is not true in migraine (Anthony and Lance, 1971).

The interest of research-workers has been centering more on serotonin, especially since the discovery of a prophylactic anti-migraine action on the part of certain serotonin antagonists.

Sicuteri et al. (1961), noted increased excretion of 5-hydroxyindoleacetic acid (5-HIAA), the main metabolite of serotonin, during migraine attacks. This finding was confirmed by Lance's group (Curran et al, 1965) and by Kangasniemi et al. (1972b) and others.

Shortly after, Lance's group found that the plasma serotonin level is slightly increased before and is greatly reduced during the attack (Anthony et al., 1967; Lance, 1969). This has been confirmed by Hilton and Cumings (1972).

There is indirect evidence that in migraine subjects the receptor sites of the blood platelets accept and retain serotonin less readily than in healthy individuals (Hilton and Cumings, 1972).

These three related findings indicate that at the start of a migraine attack serotonin is released from its natural storage site, the blood platelets, and is then excreted in the form of 5-HIAA, resulting in the observed fall in serotonin plasma level.

Serotonin exerts a vasoconstrictor effect on the extracranial arteries (Lance et al., 1967), and a vasodilator effect on the capillaries. This finding led Lance to suppose that the fall in plasma serotonin levels during migraine attacks is one of the factors responsible for the loss of tone of the extracranial arteries and for their passive distension, the more so since the capillaries are constricted at the same time (Lance, 1969); and indeed sufferers of true migraine are almost always pale during attacks.

This probable role of reduced blood serotonin in the genesis of migraine headache is corroborated by the fact that monoamine oxidase inhibitors, which prevent the breakdown of serotonin, have a certain preventive action on migraine (Kimball et al., 1960; Perrault, 1963).

Further, injection of reserpine, which reduces the serotonin level artificially by causing depletion of blood platelets and increased excretion of 5-HIAA (Figure 1), can precipitate a typical attack of migraine, which in turn can be relieved by injection of serotonin (Anthony et al., 1969).

The hypothesis proposed by Lance et al. (1967), attributing a major role to the fall in blood serotonin levels, is thus a very likely one, although a possible role of serotonin depletion in the brain - also caused by reserpine and prevented by MAO inhibitors - should also be borne in mind. Sicuteri (1973) recently demonstrated the preventive effect of treatment with 5-hydroxytryptophan, a serotonin precursor which can cross the blood-brain barrier and gives rise to an increase in serotonin levels in the brain.

Whatever the case may be, a pathogenic role of a peripheral and/or central reduction in serotonin levels might appear difficult to reconcile, at first sight, with the prophylactic antimigraine effect of 
TABLE I

Inhibiting Effect of Analgesics and Serotonin-Antagonists on Spasms Provoked by Intra-Peritoneal Injection of Acetic Acid in Mice

\begin{tabular}{|c|c|}
\hline & $\begin{array}{c}\text { ED } 50 \\
\mathbf{M g} / \mathbf{K g}_{\mathbf{g}} \text { s.c. } \\
1 \text { h. before Acetic Acid }\end{array}$ \\
\hline $\begin{array}{l}\text { Morphine } \\
\text { Aminopyrin }\end{array}$ & $\begin{array}{l}0.18 \\
34.0\end{array}$ \\
\hline LSD 25 & 0.17 \\
\hline Methysergide $\begin{array}{l}\text { Sansert } \\
\text { Deseril }\end{array}$ & 3.0 \\
\hline
\end{tabular}

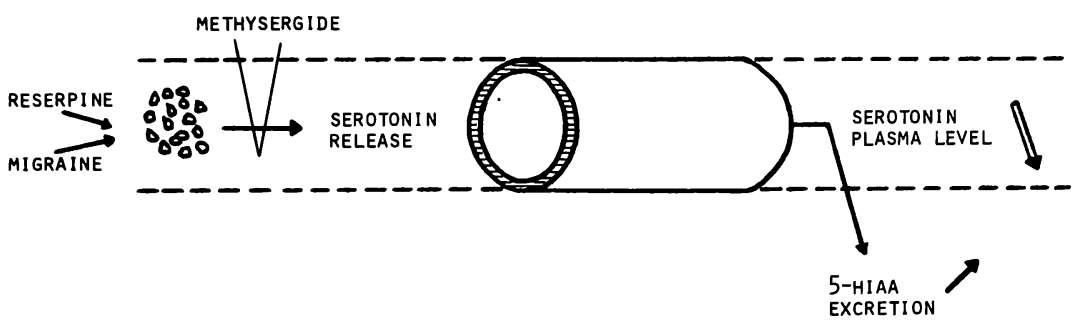

Figure 1-An injection of reserpine mimicks the changes affecting serotonin during a migraine attack: release from blood platelets, increased excretion in the form of 5-HIAA, a fall in plasma level. It is not surprising that an injection of reserpine should precipitate a typical migraine attack in susceptible subjects, and that this attack can be aborted by an injection of serotonin. The reserpine-induced serotonin release is antagonized by methysergide.

SPASMS PROVOKED BY INTRAPERITONEAL INJECTION OF ACETIC ACID IN MICE EFFECT OF A PREVIOUS INJECTION OF SUBSTANCE $48 / 80$

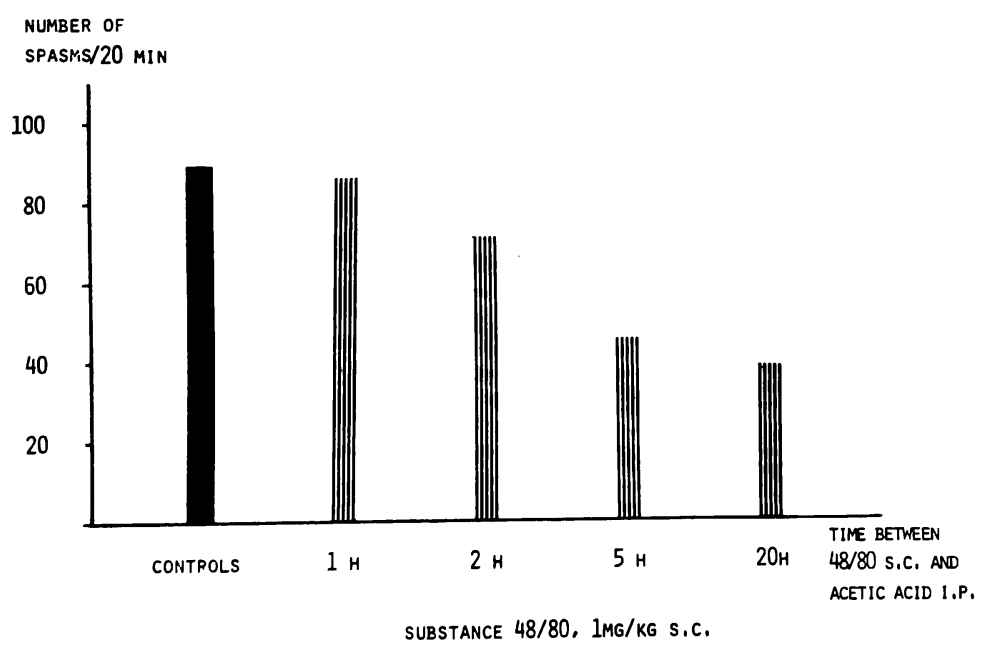

Figure 2-Intraperitoneal acetic acid test in mice. Previous injection of substance $48 / 80$ reduces the pain reaction (writhing); an optimum effect is obtained with a time lag of 5-20 hours to permit maximum depletion of serotonin. The ordinates show the average number of spasms per animal over 20 minutes. serotonin antagonists. In fact, however, there is no real contradiction even if the "serotonin-like" effect of these antagonists postulated by Lance (1969), but never demonstrated, is left out of consideration. In addition to its effects on vascular tone, serotonin possesses humoral properties which give it two other sites of action in the mechanism of migraine headache:

- Like histamine, serotonin increases capillary permeability, and its release promotes transudation of plasmakinins.

-Furthermore, it has been proved in animals and man that serotonin exerts a peripheral pain-sensitizing action.

In an experimental study in mice, Neuhold and Taeschler (1963) showed that the painful reaction to intraperitoneal injection of acetic acid, manifested as writhing of the trunk and limbs, requires the presence of serotonin. If serotonin depletion is brought about by previous injection of substance 48/80 (Figure 2 ), or of reserpine (Figure 3), the writhing reaction is attenuated. Substance $48 / 80$ also causes depletion of histamine, but the latter plays no part in the causation of the pain, since depletion of histamine alone by polymyxin $B$ does not affect the painful reaction (Figure 4). If the breakdown and depletion of endogenous serotonin is prevented by a monoamine oxidase inhibitor, substance $48 / 80$ no longer diminishes the painful reaction (Figure 5). The same is true if exogenous serotonin is injected previously (Figure 6). Finally, the writhing reaction is reduced not only by morphine, but also by serotonin antagonists such as LSD 25 or methysergide (Table I).

A similar facilitating role of serotonin in pain causation was shown in man by Sicuteri et al. (1965), who injected serotonin or a plasmakinin, bradykinin, into a vein of the back of the hand. Neither bradykinin (1 Mg ) nor serotonin $(250 \mu \mathrm{g})$ injected alone produced a local pain. But if bradykinin ( $0.1 \mu \mathrm{g})$ is preceded by an injection of 
SPASMS PROVOKED BY INTRAPERITONEAL INJECTION OF ACETIC ACID IN MICE EFFECT OF A PREVIOUS INJECTION OF RESERPINE

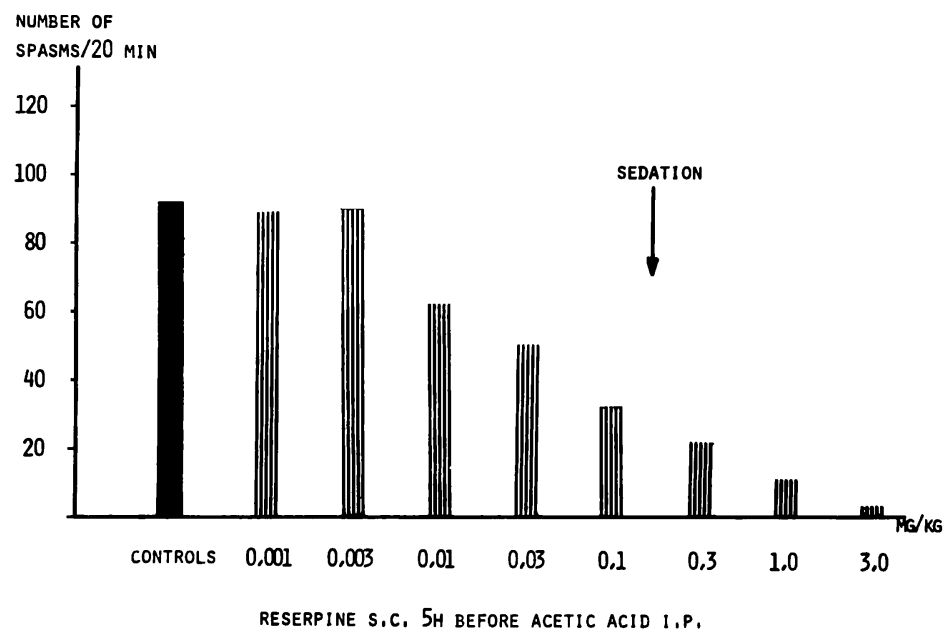

Figure 3-Dose-effect relation of reserpine, a serotonin depleting agent, on the writhing reaction to intraperitoneal acetic acid. A considerable preventive effect is obtained with a dose of reserpine $(0.1 \mathrm{mg} / \mathrm{kg})$ that does not yet produce sedation.

serotonin $(250 \mu \mathrm{g}) 2$ minutes previously, a severe pain ensues.

The effects of the release of serotonin from the platelet stores are thus of two orders:

- on the one hand an increased serotonin excretion and a fall in blood level, contributing to the hypotonia of the extracranial vessels;

SPASMS PROVOKED BY INTRAPERITONEAL INJECTION OF ACETIC ACID IN MICE EFFECT OF A PREVIOUS INJECTION OF POLYMYXIN B

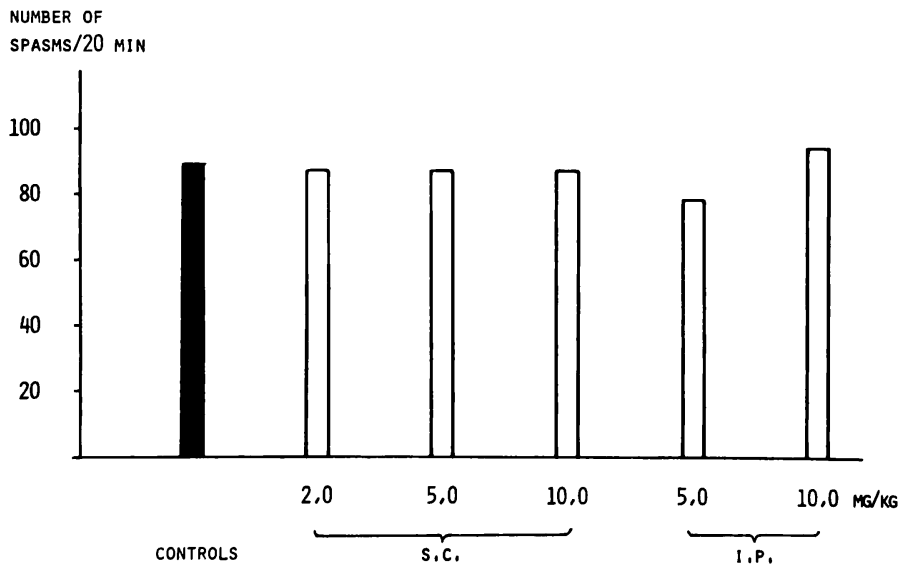

POLYMYXIN B, 24 H BEFORE ACETIC ACID I,P,

Figure 4-Intraperitoneal acetic acid test. The inactivity of polymyxin $B$, which releases exclusively histamine, shows that the preventive effect of substance $48 / 80$ is not related to histamine depletion. headache: methysergide stabilizes the vessel tone, potentiates catecholamines and inhibits the serotonin-releasing effect of reserpine on platelets (Owen et al., 1971); pizotifene or BC 105 inhibits the re-uptake of noradrenaline in nerve endings as well as the uptake of serotonin at storage sites (Salzmann and Kalberer, 1973), and exerts potent antihistamine and moderate antibradykinin action (Roemer, 1965 and 1969).

Let us now attempt to arrange this harvest of data into a logical chain of events leading to the migraine headache. As a first step, it is possible to confirm the theory of Wolff (1963) according to which two elements must be present to elicit a migraine headache:

-a loss of tone of the extracranial arteries, giving rise to their passive distension (especially if the capillaries are simultaneously constricted)

-an increased sensitivity of the pain receptors of the arterial walls, corresponding to a lowered pain threshold of these structures.

A further step is depicted in Figure 7 , which illustrates the following hypothetical mechanism. At the start of the attack the blood platelets release serotonin (1), while mast cells release histamine and proteolytic enzymes (2). Serotonin and histamine increase capillary permeability (3), thus promoting transudation of a plasmakinin (4) (produced by the action of the liberated enzymes on plasmakininogen) into the vascular wall and perivascular tissue. The combined action of a plasmakinin (5) and serotonin (6) on the receptors in the arterial walls reduces their pain threshold (7).

On the other hand, the greatest part of released serotonin is excreted by the kidneys as 5-hydroxyindoleacetic acid (8), so that plasma serotonin level declines (9). The fall in blood serotonin induces a reduction in tone of the extracranial vessels and a concomitant capillary constriction (10), leading to passive distention of these arteries (11). The 
two elements necessary to produce headache (12) are thus present: a lowering of the pain threshold and arterial distension.

\section{PRECIPITATING FACTORS}

Research in the last few years has led to the identification of several factors which could intervene, in certain types of migraine, to trigger the vasculo-humoral mechanism described above. Two factors whose roles have been relatively well established, and two others which are still very hypothetical will be discussed.

Tyramine, the sympathomimetic action of which comes about chiefly by way of liberation of noradrenaline at the nerve endings, is found in several foods, especially in certain sorts of cheese. Hanington (1967) and Hanington et al. (1970) discovered that this amine can precipitate a typical migraine attack, after a latency of $2-15 \mathrm{~h}$, in sufferers of dietary migraine. According to Sandler et al. (1970), an enzyme deficiency renders these patients incapable of degradating the ingested tyramine in the intestine, so that it is absorbed and passes into the bloodstream. Tyramine releases noradrenaline, which does not seem to play an important part in the genesis of migraine pain. It also releases serotonin from the blood platelets (Bartholini et al., 1961). In vitro studies by Genefke et al. (1973) have shown that this tyramine-induced release is higher in migraine sufferers than in normal subjects, and that tyramine inhibits the uptake of serotonin in the platelets (Genefke and Dalsgaard-Nielsen, 1973; Dalsgaard-Nielsen and Genefke, 1973). The mechanism is thus similar to that of attacks triggered by reserpine.

The fall in plasma estrogen levels appears to be a precipitating factor in menstrual migraine. Somerville (1972) observed that if the fall in the estrogen level is delayed for a few days by injection of estradiol which does not prevent menstruation from occuring within the normal time - the migraine attack is delayed for the same period. This is however not the only factor at work,
SPASMS TROVOKED BY INTRA-PERITCNEAL IIIJECTION OF ACETIC ACID III MICE EFFECT OF PREVIOUS INJECTIONS OF 48/80 FOLLOMED BY A MAO-INHIBITOR
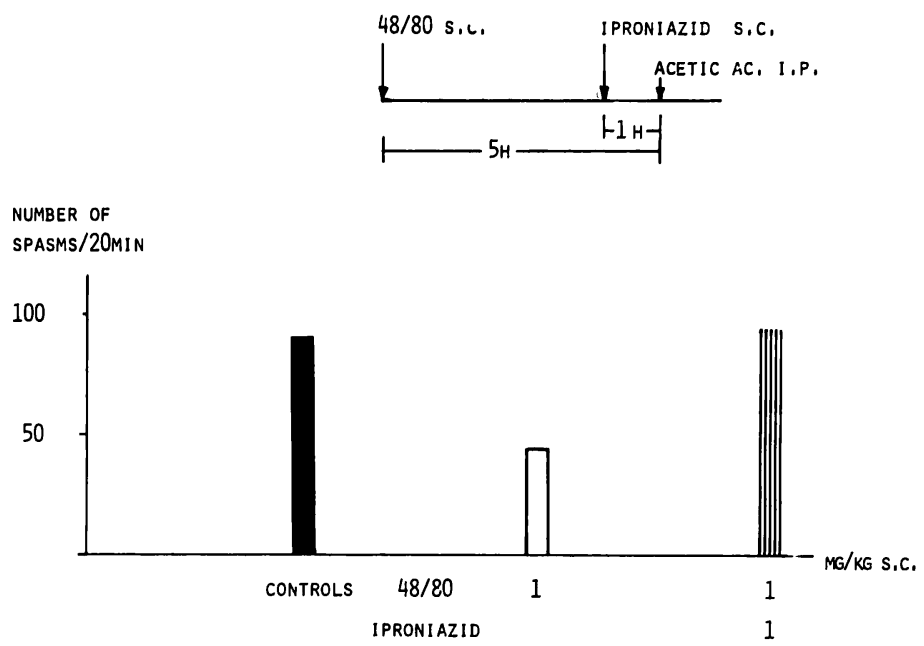

Figure 5-Intraperitoneal acetic acid test. Iproniazid reverses the protective effect of substance $48 / 80$ on the writhing reaction. Iproniazid acts as a monoamine oxidase inhibitor, thus preventing the degradation of serotonin released by $48 / 80$. since at mid-cycle, after the peak of the ovulation phase, there is an even more rapid decline in estrogen level which is rarely followed by migraine in these patients. Progesterone, which is also reduced in parallel with estrogen before menstruation, does not play a part in this respect, since the attack of migraine occurs even if high plasma levels of progesterone are maintained by daily injections.

Prostaglandins have been adduced as possible precipitating factors of migraine (Sandler, 1972), since intravenous injection of prostagladin $\mathrm{E}_{1}\left(\mathrm{PGE}_{1}\right)$ can give rise to migraine headache (Bergström et al., 1968). $\mathrm{PGE}_{1}$ is retained and partly de-
SPASMS PROVOKED BY INTRA-PERITONEAL INJECTION OF ACETIC ACID IN MICE EFFECT OF SEROTONIN (5-HT) 0.03 MG/KG I.P. PRECEDED BY RESERPIN OR 48/80

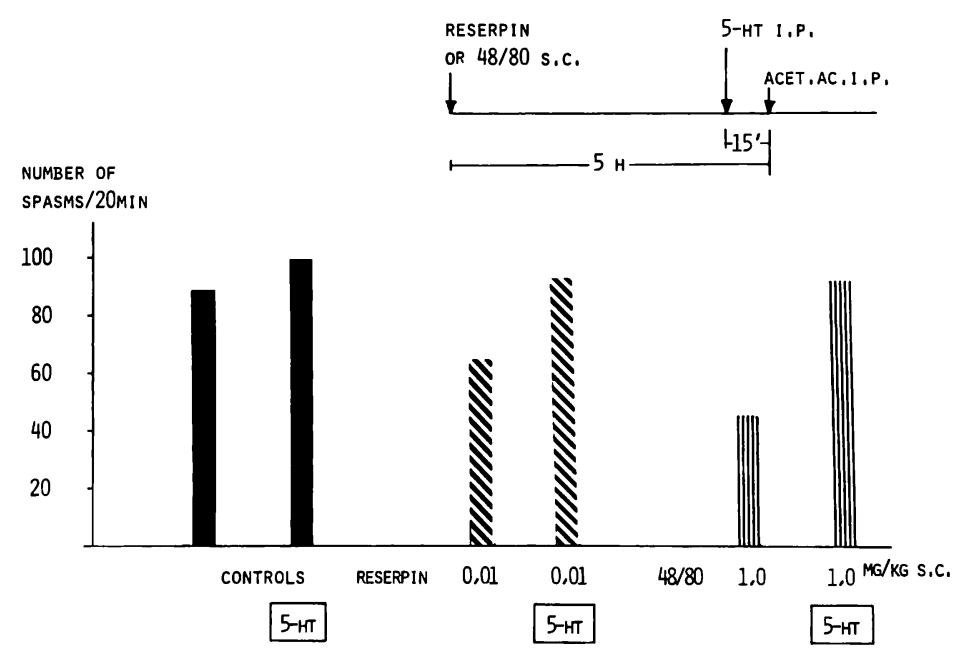

Figure 6-Intraperitoneal acetic acid test in mice. Injection of exogenous serotonin 15 minutes before acetic acid potentiates the painful reaction in controls and reverses the protective effect of serotonin depletion obtained with reserpine or substance $48 / 80$. 
stroyed in the lungs, and is released by infusion of serotonin or other amines; this release can be blocked by an antiserotonin, methysergide. These phenomena, observed in laboratory animals, have not yet been confirmed in man. If they do occur in humans, Sandler suggests that liberation of prostaglandin from the lungs in response to a suitable triggering agent could be a factor in the migraine mechanism.

The part played by prolactin is even more hypothetical. Horrobin (1973) points out that prolactin reduces urinary excretion of water, sodium and potassium, and that such reduced elimination is seen just before the migraine attack; that certain factors that stimulate prolactin secretion - reserpine, estrogens, stress - can also precipitate an attack; that serotonin also stimulates prolactin secretion, and that serotonin inhibitors have anti-migrainous properties; finally, that certain drugs - ergot derivatives, clonidine, MAO inhibitors - which reduce prolactin secretion are also useful in the treatment of migraine. While these arguments are at best circumstantial, we decided to study an in-

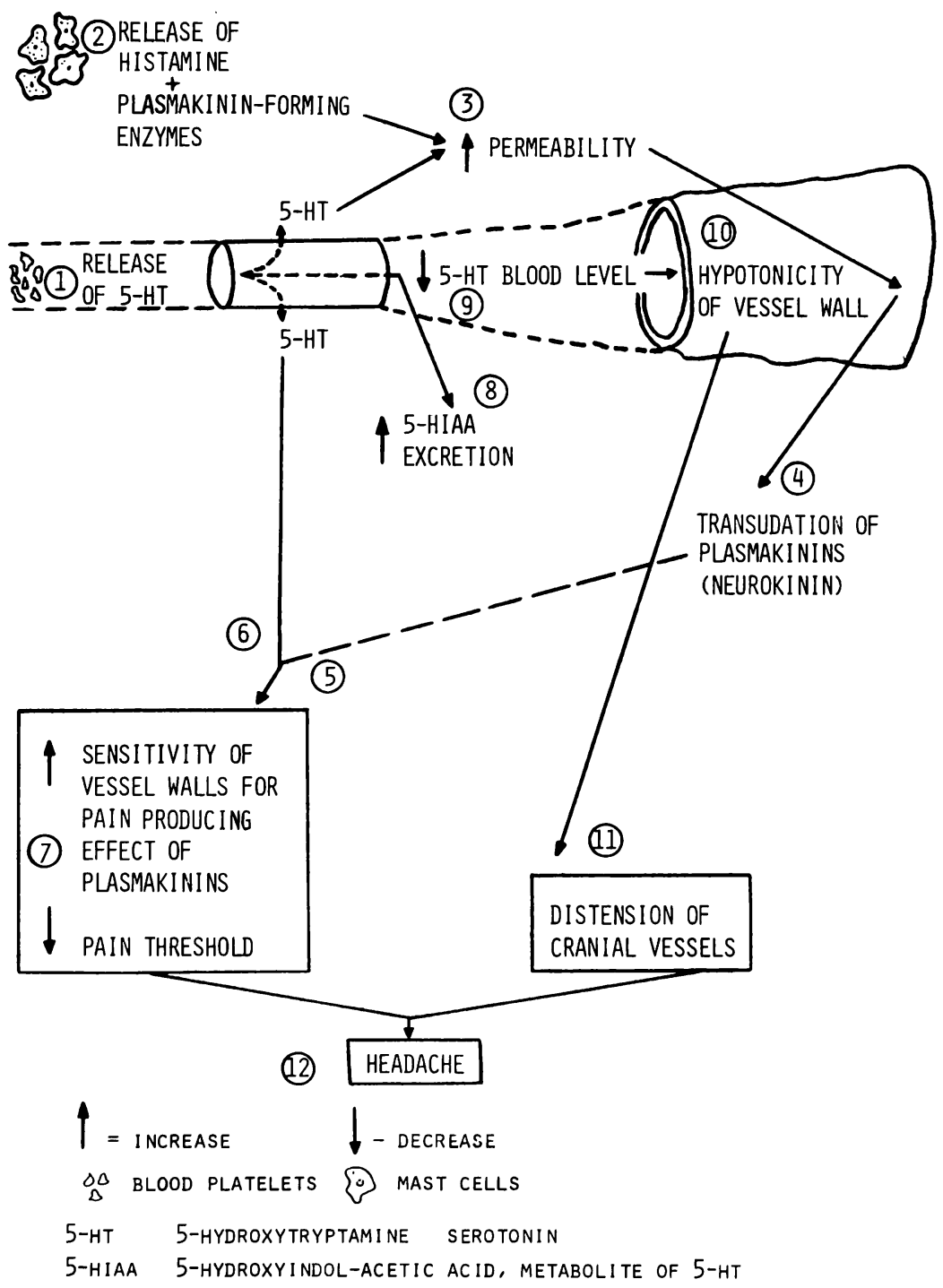

Figure 7-Hypothetical mechanisms leading to migraine headache. The circled numbers refer to those in the text.

hibitor of prolactin secretion as a preventive treatment for migraine. Preliminary results are not very encouraging.

\section{REFERENCES}

ANTHONY M., HINTERBERGER H., LANCE J. W. (1967). Plasma serotonin in migraine and stress. Archives of Neurology, 16, 544-552.

ANTHONY M., HINTERBERGER H., LANCE J. W. (1969). The possible relationship of serotonin to the migraine syndrome. Research and Clinical Studies of Headache, 2, 29-59.

ANTHONY M., LANCE J. W. (1971). Histamine and serotonin in cluster headache. Archives of Neurology, 25, 225-231.

BARTHOLINI, G., PLETSCHER, A., GEY, K. F. (1961). Diminution of 5-hydroxytryptamine in thrombocytes in vitro by chlorpromazine and related compounds. Experienta, 17, 541-542.

BERGSTROEM, S., CARLSON, L. A., WEEKS, J. R. (1968). The prostaglandins: a family of biologically active lipids. Pharmacological Reviews, 20, 1-48.

CURRAN, D. A., HINTERBERGER, H., LANCE, J. W. (1965). Total plasma serotonin, 5-hydroxyindoleacetic acid and p-hydroxy-m-methoxymandelic acid excretion in normal and migrainous subjects. Brain, London, 88, 997-1008.

DALSGAARD-NEILSEN, T., GENEFKE, I. K. (1973). Serotonin (5-hydroxytryptamine) release and uptake by platelets from healthy persons and migrainous patients in attackfree intervals. Meeting Scandinavian Migraine Society, Copenhagen, October 5-6, 1973.

GENEFKE, I. K., DALSGAARD NIELSEN, T. (1973). The effect of tyramine on the transport of 5-hydroxytryptamine in blood platelets. Acta pharmacologica et toxicologica, 33, 74-78.

GRAHAM, J. R., WOLFF, H. G. (1937). Mechanism of migraine headache and action of ergotamine tartrate. The Proceedings of the Association for Research in Nervous and Mental Disease, 18, 638-669.

HANINGTON, E. (1967). Preliminary report on tyramine headache. British Medical Journal, 2, 550-551.

HANINGTON, E., HORN, M., WILKINSON, M. (1970). Further observations on the effects of tyramine. Background to Migraine (W. Heinemann, London), 3, 113-119.

HILTON, B. P., CUMINGS, J. N. (1972). 5-hydroxytryptamine levels and platelet aggregation responses in subjects with acute migraine headache. Journal of Neurology, Neurosurgery and Psychiatry, 35, 505-509.

HOPSU, V. K., GLENNER, G. G. (1963). Further observations on histochemical esterase and amidase activities with similarities to trypsin. Journal of Histochemistry and Cytochemistry 11. 520-528. 
HORROBIN, D. F. (1973). Prevention of migraine by reducing prolactin levels? The Lancet, 1, 777.

KANGASNIEMI, P., RIEKKINEN, P., RINNE, U. K. (1972a). Kallikrein-like esterase and peptidase activities in CSF during migraine attacks and free intervals. Headache, 12, 66-68.

KANGASNIEMI, P., SONNINEN, V., RINNE, U. K. (1972b). Excretion of free and conjugated 5-HIAA and VMA in urine and concentration of 5-HIAA and HVA in CSF during migraine attacks and free intervals. Headache, 12, 62-65.

KIMBALL, R. W., FRIEDMAN, A. P., VALLEJO, E. (1960). Effect of serotonin in migraine patients. Neurology, 10, 107-111.

LANCE, J. W. (1969). The mechanism and management of headache. Butterworth, London.

LANCE, J. W., ANTHONY, M., GONSKI, A. (1967). Serotonin, the carotid body, and cranial vessels in migraine. Archives of Neurology, 16, 553-558.

NEUHOLD, K., TAESCHLER, M. (1963). Ueber die Rolle des Serotonin bei dem durch intraperitoneale Injektion von Essigsäure ausgelösten Schmerzphänomen bei der Maus. Naunyn Schmiedeberg's Archiv für experimentelle Pathologie und Pharmakologie, 245, 130-131.

O'BRIEN, M. D. (1971). Cerebral blood changes in migraine. Headache, 10 , 130-143.

O'BRIEN, M. D. (1971). The relationship between aura symptoms and cerebral blood flow changes in the prodrome of migraine. Proceedings of the International Headache Symposium, Elsinore, Denmark, 16-18, May 1971. Ed. by: D. J. Dalessio, T. Dalsgaard-Nielsen, S. Diamond, pp. 141-143.

OSTFELD, A. M., GOODELL, H., WOLFF, H. G. (1958). Studies in headache mechanisms. Archives of Internal Medicine, 101, 755-760.

OWEN, D. A. A., HERD, J. K., KALBERER, F., PACHA, W., SALZMANN, R. (1971). The influence of ergotamine and methysergide on the storage of biogenic amines. Proceedings of the International Headache Symposium, Elsinore, Denmark, 16-18, May 1971. Ed. by: D. J. Dalessio, T. Dalsgaard-Nielsen, S. Diamond, pp. 201-203.

PERRAULT, M. (1963). Migraines sévères, I.M.A.O. et méthysergide. Le Progrès Médical, 91, 413-422.

ROEMER, D. (1965 and 1969). Biological and Medical Research, Sandoz Ltd., Basle, personal communication.

SANDLER, M. (1972). Migraine: a pulmonary disease? The Lancet 1, 618-619.

SANDLER, M., YOUDIM, M. B. H., SOUTHGATE, J., HANINGTON, E. (1970). The role of tyramine in migraine: some possible biochemical mechanisms. Background to Migraine (W. Heinemann, London), 3, 103-112.

SALZMANN, R., KALBERER, F. (1973) Antimigraine drugs and storage of serotonin. Background to Migraine (W. Heinemann, London), 5, 63-72.
SICUTERI, F. (1963). Mast cells and their active substances: their role in the pathogenesis of migraine. Headache, 3, 86-92.

SICUTERI, F. (1973). The ingestion of serotonin precursors (L-5-hydroxytryptophan and L-tryptophan) improves migraine headache. Headache, 13, 19-22.

SICUTERI, F., FANCIULLACCI, M., FRANCHI, G., DEL BIANCO, P. L. (1965). Serotonin - bradykinin potentiation on the pain receptors in man. Life Sciences, 4, 309-316.

SICUTERI, F., TESTI, A., ANSELMI, B. (1961). Biochemical investigations in headache: increase in the hydroxyindoleacetic acid excretion during migraine attacks. International Archives of Allergy and applied Immunology, 19, 55-58.

SKINH ØJ, E. (1971). The value of regional cerebral blood flow studies in migraine research. Proceedings of the International Headache Symposium, Elsinore, Denmark, 16-18, May 1971. Ed. by: D. J. Dalessio, T. Dalsgaard-Nielsen, S. Diamond, pp. 201-203.

SKINHØJ, E., PAULSON, O. B. (1969). Regional blood flow in internal carotid distribution during migraine attack. British Medical Journal, 3, 569-570.

SOMERVILLE, B. W. (1972). The role of estradiol withdrawal in the etiology of menstrual migraine. Neurology, 22, 355-365.

WOLFF, H. G. (1963). Headache and other head pain. Oxford University Press, New York (1st Edition 1948). 